\title{
Glyphosate as a Tool to Produce Shikimic Acid in Plants ${ }^{1}$
}

\author{
Glyphosate como Ferramenta para Produzir Ácido Chiquímico em Plantas
}

MATALLO, M.B. ${ }^{2}$, ALMEIDA, S.D.B. ${ }^{2}$, FRANCO, D.A.S. ${ }^{2}$, CERDEIRA, A.L. ${ }^{3}$, and GAZZIERO, D.L.P. ${ }^{4}$

\begin{abstract}
Oseltamivir phosphate is a potent viral inhibitor produced from shikimic acid extracted from seeds of Ilicium verum, the most important natural source. With the site of action 5-enolpyruvylshikimate-3-phosphate synthase (EPSP), glyphosate is the only compound capable of inhibiting its activity with the consequent accumulation of shikimic acid in plants. Corn and soybean plants were sprayed with reduced rates of glyphosate (0.0 to $230.4 \mathrm{~g}$ a.i. ha $\left.\mathrm{h}^{-1}\right)$ and shikimic acid content in the dry mass was determined by HPLC 3, 7 and 10 days after application. Results showed shikimic acid accumulation in dry mass with increases of up to $969 \%$ in corn and $33,000 \%$ on soybeans, with peak concentrations 3 days after treatment (DAT). Industrial feasibility for shikimic acid production, combined with favorable climatic conditions for growing corn and soybean in virtually all over Brazil, favor the use of reduced rates of glyphosate in shikimic acid biosynthesis, with potential for use as an inducer in exploration of alternative sources for production of oseltamivir phosphate with low environmental impact.
\end{abstract}

Keywords: herbicides, corn, soybean, Oseltamivir, pandemics, HPLC.

\begin{abstract}
RESUMO - O fosfato de oseltamivir, ingrediente ativo do antiviral Tamiflu , é um potente inibidor viral produzido a partir do ácido chiquimico e extraido da semente de Ilicium verum, sua mais importante fonte natural. Tendo como sitio de ação a enzima 5 enolpiruvilchiquimato-3-fosfato sintase (EPSPs), o glyphosate é o único composto capaz de inibir a sua atividade, com o consequente acúmulo do ácido chiquimico nas plantas. Plantas de milho e soja foram pulverizadas com subdoses de glyphosate (0,0 a 230,4 g e.a. ha-1), determinando-se o teor de ácido chiquímico na massa seca dessas plantas por HPLC aos 3,7 e 10 dias após aplicação. Os resultados mostraram acúmulo de ácido chiquímico na massa seca dessas plantas, com aumento de até $969 \%$ no milho e 33.000\% na soja, com picos de concentração aos 3 DAT. A praticabilidade industrial do processo de obtenção do ácido chiquimico, aliada às condições edafoclimáticas favoráveis ao plantio de milho e soja em diversos paises, favorece o uso de subdoses de glyphosate na biossintese de ácido chiquimico, com potencial para ser explorado como indutor na produção do fosfato de oseltamivir com baixo impacto ambiental.
\end{abstract}

Palavras-chave: herbicidas, milho, soja, fosfato de oseltamivir, pandemias, HPLC.

\section{INTRODUCTION}

Periodically, mankind is struck by influenza pandemics, with fatal consequences. The first influenza pandemic recorded in the 21 st century caused by the H1N 1 virus lasted 14 months (Martirosyan et al., 2012). In Brazil, 30,854 cases of SARS were reported in 2009; $19.8 \%$ of these $(6,100)$ were confirmed as cases of influenza by laboratory testing, and $85.3 \%$
$(5,206)$ were confirmed for the influenza virus A (H1N1), with $10.7 \%$ of deaths (São Paulo, 2009 ). With a mortality rate of over $50 \%$, avian flu caused by the H5N1 virus has aroused increasing concern due to the possibility of the mutant virus to acquire the ability to infect humans, causing new pandemics. Thus, the development of effective measures to combat these viruses is of crucial importance to human health.

1 Recebido para publicação em 29.10.2013 e aprovado em 24.2.2014.

2 Instituto Biológico, Campinas-SP, Brasil, <matallo@biologico.sp.gov.br>; ${ }^{3}$ Embrapa, Jaguariúna-SP, Brasil; ${ }^{4}$ Embrapa, Londrina-PR Brasil. 
Neuramidases are glycoside hydrolase enzymes that cleave the glycosidic bonds of neuraminic acid, and they are essential for viral replication (Forleo-Neto et al., 2003). Oseltamivir phosphate is a potent inhibitor of viral neuraminidase, discovered in 1997 (Kim et al., 1997) and launched in 1999 by the pharmaceutical company Roche, marketed under the brand name Tamiflu ${ }^{\circledR}$. It is used against various strains of influenza virus, including $\mathrm{H} 1 \mathrm{~N} 1$ and $\mathrm{H} 5 \mathrm{~N} 1$ (Kramer et al., 2003).

Currently, oseltamivir phosphate is produced from shikimic acid, in a complex synthesis process involving 11 phases (Abrecht et al., 2007). Shikimic acid is a scarce and expensive chemical, obtained mainly from seeds of Ilicium verum, a shrub native of China popularly known as Chinese star anise, and I. anisatum, native of Japan (Sadaka \& Garcia, 1999; Payne \& Edmonds, 2005). In a conservative estimate, Bradley (2005) states that $520,000 \mathrm{~kg}$ of shikimic acid are needed for producing Tamiflu ${ }^{\circledR}$ in the event of a pandemic affecting 400 million people, compared to a current annual production of $100,000 \mathrm{~kg}$ of this acid.

Measurement of shikimic acid accumulation in response to glyphosate inhibition of enzyme EPSPs is used not only to determine plant exposure to this herbicide (Henry et al., 2007) but also to quickly and accurately identify resistant weeds (Muller et al, 2003;. Koger et al, 2005a), to distinguish resistant from susceptible soybean and cotton cultivars (Pline et al, 2002; Bonini et al., 2009), and to check its effect on the metabolism of aromatic amino acids in Cyperus rotundus (Wang, 2001). Transitory in nature, shikimic acid accumulation has been reported to occur one day after glyphosate application, reaching peak levels between four and seven days afterwards (Koger et al., 2005b).

Whereas obtaining pure shikimic acid involves relatively simple and low-cost processes (Sui, 2008), the use of reduced rates of glyphosate can be an interesting strategy for accumulating this acid for further industrial use. The process shown here may be of interest to the pharmaceutical industry, in search of options to supplement the meager supply of shikimic acid.
Based on the fact that reduced rates of glyphosate applications induce shikimic acid accumulation in plants, the aim of this study was to determine both the effect of reduced rates of glyphosate on shikimic acid accumulation in corn and soybean leaves and the period of greatest accumulation of this acid in the plants. Thus, this paper suggests that corn and soybeans plants treated with glyphosate can be considered to be alternative plant sources for the production of this acid by employing an environmentally friendly management system whereby reduced rates of this herbicide are applied.

\section{MATERIALS AND METHODS}

The trial was conducted in a factorial design with the factors glyphosate rates and sampling times with seven and three levels, respectively, with treatments arranged in a randomized block design with four replications.

Soybean cv. BRS 232 and hybrid corn BM 709 were planted on November $13^{\text {th }}, 2009$, on loamy soil classified as purple Eutrustox, in 2.0 x $10.0 \mathrm{~m}$ plots, under a completely randomized design with four replications. Soybeans were planted at a spacing of $0.5 \mathrm{~m}$ between rows at a density of 16 plants $\mathrm{m}^{-1}$, and corn was planted at a spacing of $0.5 \mathrm{~m}$ between plants, at a density of 4 plants $\mathrm{m}^{-1}$, producing a final stand 32,000 and 40,000 plants ha ${ }^{-1}$ for soybean and corn, respectively. Prior to planting, fertilization was performed on the basis of $260 \mathrm{~kg} \mathrm{ha}^{-1}$ of formula 00-20-20. To minimize the potential effect of drift between plots, all of them were separated $2.0 \mathrm{~m}$ apart. Based on the recommendation for use of the commercial product RoundUp Transorb for nonselective weed control in no-till system for corn and soybean, which ranges between 480 and $2160 \mathrm{~g} \mathrm{ha}^{-1}$ of equivalent glyphosate acid (Rodrigues \& Almeida, 2005), the treatments consisted of reduced rates of this herbicide at $0.0 ; 7.2 ; 14.4 ; 28.8 ; 57.6,115.2$; and 230.4 g a.i. ha ${ }^{-1}$ (Table 1$)$.

Treatments were applied at stages V4 and V3 for corn and soybeans, respectively, 25 days after sowing, using a backpack sprayer equipped with four nozzles spaced at $0.5 \mathrm{~m}$ and 110.02 STIA 02 (Micron) tips at constant pressure of $351 \mathrm{~b} \mathrm{in}{ }^{-2}$ maintained by $\mathrm{CO}_{2}$ 
Table 1 - Glyphosate rates applied in soybean and corn to induce shikimic acid production

\begin{tabular}{|c|c|}
\hline $\begin{array}{c}\text { Rates } \\
\left(\mathrm{g} \text { a.i. } \mathrm{ha}^{-1}\right)\end{array}$ & $\begin{array}{c}\% \text { of the minimum recommended rate } \\
\left(480 \mathrm{~g} \mathrm{a.i}^{-1}\right)\end{array}$ \\
\hline 0.0 & 0.0 \\
\hline 7.2 & 1.5 \\
\hline 14.4 & 3.0 \\
\hline 28.8 & 6.0 \\
\hline 57.6 & 12.0 \\
\hline 115.2 & 24.0 \\
\hline 230.4 & 48.0 \\
\hline
\end{tabular}

adjusted for spray volume of $200 \mathrm{~L} \mathrm{ha}^{-1}$. Upon application of the treatments, wind force was 1 according to the Beaufort scale, ranging between 4.0 and $5.0 \mathrm{~km} \mathrm{~h}^{-1}$; air temperature was $28{ }^{\circ} \mathrm{C}$ and relative air humidity was $60 \%$.

The determination of shikimic acid in soybean and corn leaves followed the procedure described by Matallo et al. (2009). At 3, 7 and 10 days after treatments (DAT), always in the morning, younger and fully developed leaves and trifoliate leaves of corn and soybeans, respectively, were randomly collected. Each sample consisted of 20 plants in each plot. The leaves and trifoliate leaves were dried in a forced air circulation oven at $60{ }^{\circ} \mathrm{C}$ for 16 hours, and after that they were crushed at 25,000 rpm (IKA A11 Basic), frozen at temperatures $\leq 10{ }^{\circ} \mathrm{C}$, stored in polystyrene boxes, sealed and transported to the laboratory. The extraction of shikimic acid was performed in replicates of $100 \mathrm{mg}$ of dry matter, mixed with $5 \mathrm{~mL}$ of water acidified to $\mathrm{pH} 2$ with phosphoric acid in a microwave oven (Panasonic NN-S62B) at $100 \mathrm{~W}$ for 10 seconds. The extraction temperature was $49.8{ }^{\circ} \mathrm{C} \pm$ $2.8^{\circ} \mathrm{C}$. Each sample was placed in the center of the microwave glass tray. After extraction, each sample was allowed to cool for 5 minutes and then filtered through Whatman No 1 filter paper, and 0.22 micrometre membrane filter (Millex-GV, Millipore) for quantification by HPLC.

Shikimic acid concentration in the samples was determined by a Shimadzu 2010 LC liquid chromatograph with software Class VP 6.0, automatic injector and diode array detector at a wavelength of $212 \mathrm{~nm}$ and injection volume of $20 \mu \mathrm{L}$; Phenomenex Gemini C18 $110 \mathrm{~A}^{\circ}(250.0 \mathrm{~mm} \times 4.0 \mathrm{~mm}$; $5 \mu \mathrm{m}$ particle) LC column was used. The system was performed in isocratic mode with a mobile phase ultrapure water acidified solution with phosphoric acid and methanol (95:5) at a flow rate of $1.0 \mathrm{~mL} \mathrm{~min}^{-1}$.

The results were taken in dry weight basis in order to eliminate the variability of the water content of the plants. Data were subjected to analysis of variance by the F-test, with means compared by Tukey's test, both at $5 \%$ probability.

\section{RESULTS AND DISCUSSION}

A calibration curve with concentrations of shikimic acid ranging from 2.04 to $407.2 \mathrm{mg} \mathrm{L}^{-1}$ was constructed for quantifying shikimic acid concentrations. The relationship between the concentrations and the areas of chromatographic peaks was linear, with a correlation coefficient of 0.9999 . Through this method, the detection threshold was $0.395 \mathrm{mg} \mathrm{L}^{-1}$. In the terms of the analytical method, shikimic acid eluted at 4.8 minutes, for a total analysis time of 10 minutes.

Tables 2 and 3 show, respectively, the concentration of shikimic acid in corn and soybean determined at 3, 7 and 10 days after glyphosate application, besides the ratio relative to the endogenous level of control plants.

In the case of corn (Table 2), the values of $p \leq 0.05$ for rates and time indicate that these factors had a significant effect on shikimic acid concentrations; rather, the interaction between them showed that the behavior of rates did not differ significantly within each sampling time, and vice versa $(p=0.69)$. Glyphosate when applied at rates of 115.2 and $230.4 \mathrm{~g} \mathrm{ha}^{-1}$, significantly increased shikimic acid concentration in corn leaves at 3 DAT increasing, respectively, 4.97 and 9.73 times its concentration compared to the one found in control plants. Shikimic acid concentration also increased significantly by 9.85 times and 11.25 at 7 and 10 DAT, respectively, compared to the endogenous level of the control when glyphosate was applied at a higher rate. 
Table 2 - Shikimic acid concentration ( $\mathrm{mg} \mathrm{g}^{-1}$ ) and ratio compared with the control in corn leaves after application of different glyphosate rates

\begin{tabular}{|c|c|c|c|c|c|c|}
\hline Rate $\left(\mathrm{g} \mathrm{a.i.} \mathrm{ha}^{-1}\right)$ & 3 DAT & Ratio & 7 DAT & Ratio & 10 DAT & Ratio \\
\hline 0.0 & $0.59 \mathrm{a}$ & 1.00 & $0.52 \mathrm{a}$ & 1.00 & $0.36 \mathrm{a}$ & 1.00 \\
\hline 7.2 & $0.75 \mathrm{a}$ & 1.27 & $0.45 \mathrm{a}$ & 0.86 & $0.38 \mathrm{a}$ & 1.05 \\
\hline 14.4 & $0.57 \mathrm{a}$ & 0.97 & $0.42 \mathrm{a}$ & 0.81 & $0.46 \mathrm{a}$ & 1.28 \\
\hline 28.8 & $0.70 \mathrm{a}$ & 1.18 & $0.62 \mathrm{a}$ & 1.19 & $0.57 \mathrm{a}$ & 1.58 \\
\hline 57.6 & $1.28 \mathrm{a}$ & 2.17 & $1.16 \mathrm{a}$ & 2.23 & $0.81 \mathrm{a}$ & 2.25 \\
\hline 115.2 & $2.93 \mathrm{~b}$ & 4.97 & $1.79 \mathrm{a}$ & 3.44 & $1.99 \mathrm{a}$ & 5.53 \\
\hline 230.4 & $5.74 \mathrm{c}$ & 9.73 & $5.12 \mathrm{~b}$ & 9.85 & $4.05 \mathrm{~b}$ & 11.25 \\
\hline
\end{tabular}

Means followed by the same letter in the columns do not differ by Tukey's test at $5 \%$ probability.

Table 3 - Shikimic acid concentration $\left(\mathrm{mg} \mathrm{g}^{-1}\right)$ and ratio compared with the control in soybean leaves after application of different glyphosate rates

\begin{tabular}{|c|c|c|c|c|c|c|}
\hline Rate $\left(\mathrm{g} \mathrm{a.i.} \mathrm{ha}^{-1}\right)$ & 3 DAT & Ratio & 7 DAT & Ratio & 10 DAT & Ratio \\
\hline 0.0 & $0.12 \mathrm{a}$ & 1.00 & $0.07 \mathrm{a}$ & 1.00 & $0.10 \mathrm{a}$ & 1.00 \\
\hline 7.2 & $0.15 \mathrm{a}$ & 1.17 & $0.09 \mathrm{a}$ & 1.28 & $0.04 \mathrm{a}$ & 0.35 \\
\hline 14.4 & $0.87 \mathrm{a}$ & 7.25 & $0.15 \mathrm{a}$ & 2.21 & $0.06 \mathrm{a}$ & 0.64 \\
\hline 28.8 & $8.78 \mathrm{~b}$ & 73.16 & $2.54 \mathrm{a}$ & 37.35 & $0.18 \mathrm{a}$ & 1.80 \\
\hline 57.6 & $12.95 \mathrm{~b}$ & 107.92 & $8.47 \mathrm{~b}$ & 124.56 & $2.17 \mathrm{a}$ & 21.70 \\
\hline 115.2 & $19.55 \mathrm{c}$ & 162.92 & $14.64 \mathrm{c}$ & 215.29 & $13.47 \mathrm{~b}$ & 135.00 \\
\hline 230.4 & $21.18 \mathrm{c}$ & 176.50 & $23.03 \mathrm{~d}$ & 338.68 & $2.50 \mathrm{c}$ & 185.00 \\
\hline
\end{tabular}

Means followed by the same letter in the columns do not differ by Tukey's test at $5 \%$ probability. Means compared by the t-test at $5 \%$ probability in each rate.

For soybeans, both rates and application time and the interaction between them showed values of $\mathrm{p} \leq 0.05$, indicating significant differences in shikimic acid concentration for these factors. Significant increases, representing 73.16, 124.56 and 135.00 times the endogenous shikimic acid concentration in the control plants after 3,7 and 10 DAT, respectively, were observed when applied Glyphosate at 28.857 .6 and $115.2 \mathrm{~g}$ a.i. $\mathrm{ha}^{-1}$ with peak concentrations at 7 DAT - this corresponds to 338.68 times the concentration of control plants (Table 3 ).

Periods of maximum shikimic acid accumulation are in agreement with those reported by Henry et al. (2005), who found peak concentrations at 4 and 7 days after application of glyphosate in corn and soybean, respectively. Endogenous shikimic acid concentrations in the control plants are close to those determined in needles of Pinus spp. and seeds of Liquidambar styraciflua (Enhrich et al., 2008; Sui, 2008; Martin et al., 2010) and within the range expected for angiosperms (Hattori et al, 1954; Sambanthamurthi et al., 2010).

Starting from a significantly lower endogenous level, soybean consistently showed statistically higher concentrations than those observed in corn through the application of $57.6 \mathrm{~g}$ a.i. ha ${ }^{-1}$ (Figure 1). It is known that shikimic acid is present in several tissues from a wide variety of plants at a sufficiently high rate, and the concentration and accumulation in different tissues depends on the rate of ongoing metabolic processes (Bochkov et al. 2012). Different signaling molecules may mediate plant response to abiotic stress, and extracellular ATP accumulated a primary flag that triggers plant response, leading to the formation of reactive oxygen species, which are molecules associated with activation of primary and secondary metabolism (Jacobo-Velázquez \& Cisneros-Zevallos, 2009). Thus, a higher shikimic acid accumulation observed in 

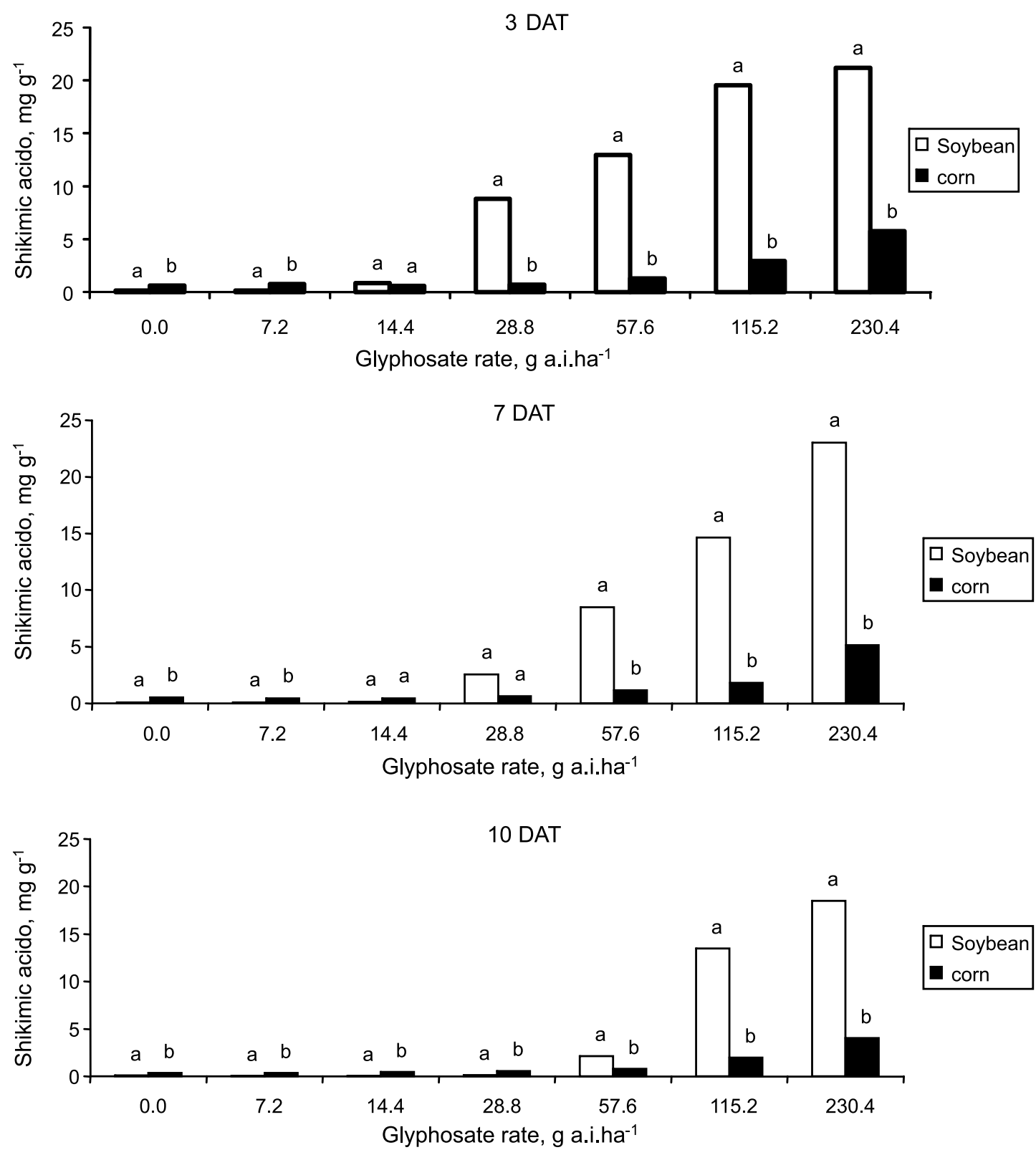

Figure 1 - Shikimic acid concentration ( $\mathrm{mg} \mathrm{g}^{-1}$ ) and glyphosate rates (g a.i. ha ${ }^{1}$ ).

soybean plants sprayed with glyphosate may be associated with a higher removal of extracellular ATP by corn plants, as reported by Brown-Becerra et al. (2012) by comparing the shikimic acid accumulation in carrot plants with previous abiotic stress, dipped and sprayed with glyphosate, with removal of extracellular ATP attributed to higher shikimic acid accumulation observed in carrot plants that had been sprayed. The dependence between glyphosate rates and shikimic acid content in corn and soybeans leaves is shown in Figure 2. In both cases there is a positive linear functional relationship between the glyphosate rate applied and the shikimic acid concentration determined by HPLC. For corn, the linear model explained 98.3, 95.5 and $96.7 \%$ of the variability in shikimic acid content at 3, 7 and 10 DAT, respectively, with a strong relationship between the variables. For soybeans, although the linear model explains $78.49 \%$ of the variability of the data 

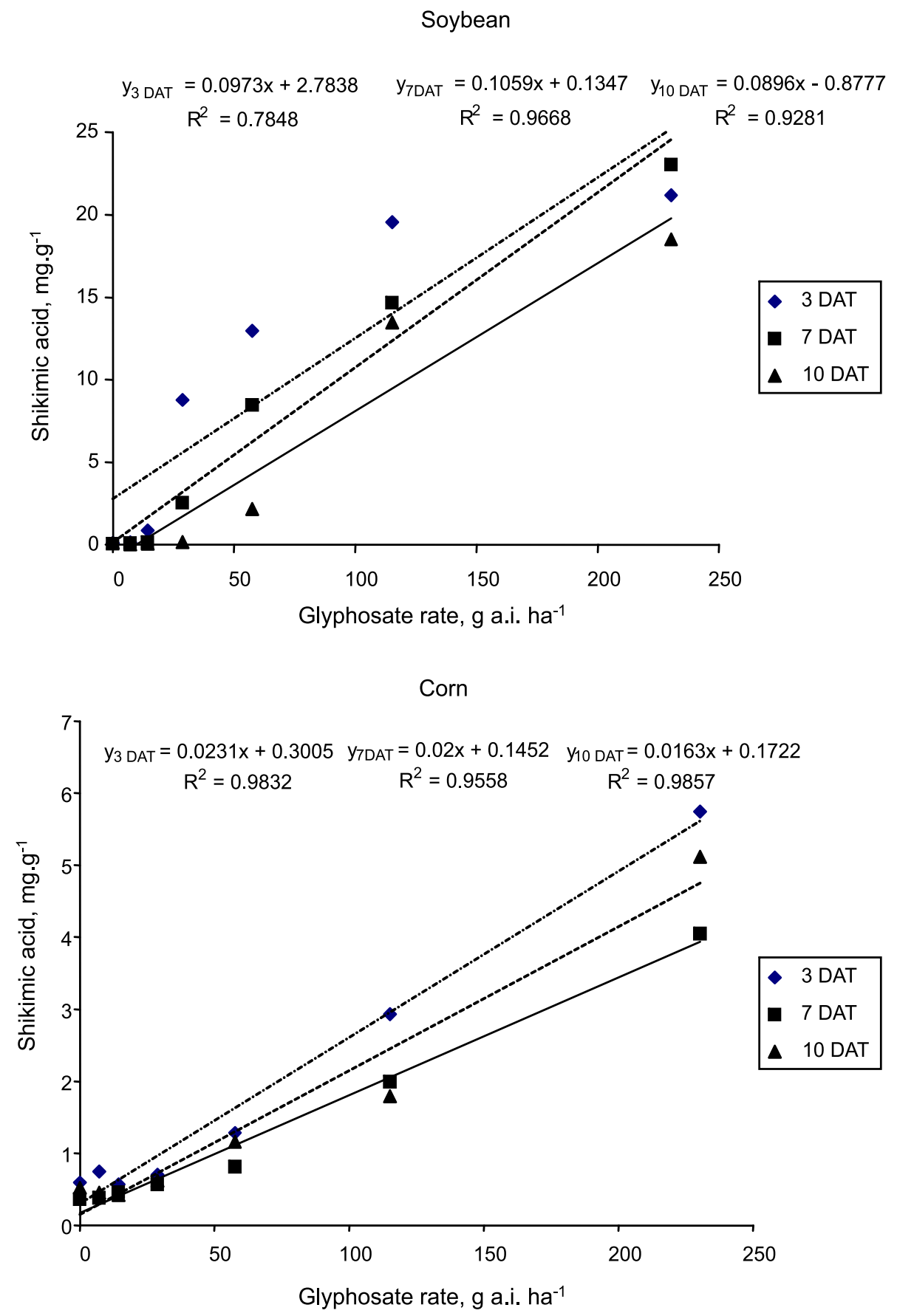

Figure 2 - Regression of shikimic acid content in leaves of corn and soybeans at 3, 7 and 10 DAT, depending on glyphosate rates.

at 3 DAT, 96.68 and $92.82 \%$ of variability is explained linearly at 7 and $10 \mathrm{DAT}$, respectively, also with strong relationship between variables. Anderson et al. (2001) also found a direct proportional relationship between glyphosate rates and shikimic acid accumulation in wheat plants.
The results showed shikimic acid accumulation in the dry mass of corn and soybeans, with increases of up to $969 \%$ in corn and $33.000 \%$ in soybeans, with peak levels at 3 DAT. The industrial feasibility of the process of shikimic acid production (Rawat et al., 2013), together with the favorable climatic 
conditions for growing corn and soybeans almost all over Brazil, favor the use of reduced rates of glyphosate in shikimic acid biosynthesis, with potential for use as an inducer in the exploration of alternative sources for the production of oseltamivir phosphate (Tamiflu $\left.{ }^{\circledR}\right)$, with low environmental impact. The results agree with those presented by Becerra-Moreno et al. (2012), who found an increase of $1,735 \%$ in shikimic acid concentration in carrots under glyphosate application.

\section{LITERATURE CITED}

ABRECHT, S. et al. The Synthetic-Technical Development of Oseltamivir Phosphate Tamiflu ${ }^{\mathrm{TM}}$ : A race against time.

Chimia, v. 61, n. 3, p. 93-99, 2007.

ANDERSON, K. A.; COBB, W. T.; LOPER, B. R. Analytical method for determination of shikimic acid: shikimic acid proportional to glyphosate application rates. Comm. Soil Sci. Plant Anal., v. 32, n. 17/18, p. 2831-2840, 2001.

BECERRA-MORENO, A. et al. Plants as biofctories: glyphosate-induced production of shikimic acid and phenolic antioxidants in wounded carrot tissue. J. Agric. Food Chem., v. 60, n. 45, p. 11378-386, 2012.

BOCHKOV, D. V. et al. J. Chem. Biol., v. 5, n. 1, p. 5-17, 2012.

BONINI, E. A. et al. A simple chromatgraphic assay to discriminate between glyphosate-resistant and suscetible soybean (Glycine max) cultivars, Eur. J. Agron., v. 31, n. 3, p. 173-76, 2009.

BRADLEY, D. Star role for bacteria in controlling flu epidemic? Nature Rev. Drug Disc., v. 4, n. 12, p. 945-946, 2005.

RESNAHAN, G. A. et al. Glyphosate applied preharvest induces shikimic acid accumulation in hard red spring wheat (Triticum aestivum). J. Agric. Food Chem., v. 51, n. 14, p. 4004-4007, 2003.

ENHRICH, L. B. et al. Liquidambar styraciflua: a renewable source of shikimic acid. Tetrah. Letters, v. 49, n. 16, p. 2503-2505, 2008.

FORLEO-NETO, E. et al. Influenza. R. Soc. Bras. Medic. Trop., v. 36, n. 2, p. 267-74, 2003.

HALTER, S. História do herbicida agrícola Glyphosate. In: VELINI, E. D. et al., (Ed.). Glyphosate. Botucatu: FEPAF, 2009. p. 11-16.
HATTORI, S.; YOSHIDA, S.; HASEGAWA, M. Occurrence of shikimic acid in the leaves of gymmnosperms. Physiol. Plant, v. 7, n. 2, p. 283-289, 1954.

HENRY, W. B.; KOGER, C. H.; SHANER, D. L. Accumulation of shikimate in corn and soybean exposed to various rates of glyphosate. Crop Manag., 2005.

HENRY, W. B.; SHANER, D. L.; WEST, M. S. Shikimate accumulation in sunflower, wheat, and poroso millet after glyphosate application. Weed Sci., v. 55, n. 1, p. 1-5, 2007.

KIM, C. U. et al. Influenza neuraminidase inhibitors possessing a novel hydrophobic interaction in the enzyme active site: Design, synthesis, and structural analysis of carbocyclic sialic acid analogues with potent anti-influenza activity. J. Am. Chem. Soc., v. 119, n. 4, p. 681-690, 1997.

JACOBO-VELÁZQUEZ, D. A.; CISNEROS-ZEVALLOS, L. C. Correlations of antioxidante activity against phenolic content revisited: A new approach in data análisis for food and medicinal plants. J. Food Sci., v. 74, n. 9, p. R107-R113, 2009.

KOGER, C. H. et al. Assessment of two nondestructive assays for detecting glyphosate resistance in horseweed (Conyza canadensis). Weed Sci., v. 53, n. 4, p. 438-445, 2005a.

KOGER, C. H. et al. Rice (Oryza sativa) response to drift rates of glyphosate. Pestic. Manag. Sci., v. 61, n. 12, p. 1161-67, 2005b.

KRÄMER, M. et al. Metabolic engineering for microbial production of shikimic acid. Metab. Eng., v. 5, n. 4, p. 277-283, 2003.

MARTIROSYAN, L. et al. The community impact of the 2009 influenza pandemic in the WHO European Region: a comparison with historical seasonal data from 28 countries. BMC Infect. Dis., 2012 12:36.

MARTIN, E. et al. Sweetgum (Liquidambar styraciflua L.): Extraction of shikimic acid coupled to dilute acid pretreatment. Appl. Biochem. Biotechnol., v. 162, n. 6, p. 1660-1668, 2010.

MATALLO, M. B. et al. Microwaved assisted solvent extraction and analysis of shikimic acid from plant tissues. Planta Daninha, v. 27, p. 987-994, 2009.

(Número Especial).

MULLER, T. C. et al. Shikimate accumulates in both glyphosate-sensitive and glyphosate-resistant horseweed (Conyza canadensis L. Cronq.) J. Agric. Food Chem., v. 51, n. 3, p. 680-684, 2003.

PAYNE, R.; EDMONDS, M. Isolation of shikimic acid from star aniseed. J. Chem. Ed., v. 82, n. 4, p. 599-600, 2005.

Planta Daninha, Viçosa-MG, v. 32, n. 3, p. 601-608, 2014 
PLINE, W. A. et al. Tolerance and accumulation of shikimic acid in response to glyphosate applications in glyphosateresistant and nonglyphosate-resistant cotton. J. Agric. Food Chem., v. 50, n. 3, p. 506-512, 2002.

RAWAT, G.; TRIPATHI, P.; SAVENA, R. K. Expanding horizons of shikimic acid. Appl. Microbiol. Biotechnol., v. 97, n. 10, p. 4277-4287, 2013.

RODRIGUES, B. N.; ALMEIDA, F. L. S. Guia de herbicidas. 5.ed. Londrina: GrafMark, 2005. p. 275-289.

SADAKA, M.; GARCIA, A. Extraction of shikimic and quinic acids. Chem. Eng. Comm., v. 173, n. 1, p. 91-102, 1999.
SAMBAnthamurthi, R. et al. Oil Palm Phenolics as a Source of Shikimic Acid an MPOB-MIT Collaboration. MPOB Information Series, June 2010.

SÃO PAULO. Secretaria de Vigilância em Saúde. Inf. Epidemiol. Influenza A (H1N1), v. 6, n. 1, p. 1-10, 2009.

SUI, R. Separation of shikimic acid from Pine Needles. Chem. Eng. Technol., v. 31, n. 3, p. 469-473, 2008.

WANG, C. Effect of glyphosate on aromatic amino acid metabolism in Purple Nutsedge (Cyperus rotundus). Weed Technol., v. 15, n. 4, p. 628-635, 2001. 